\title{
Collaborative Worldbuilding for Writers and Gamers
}

\author{
Jennifer Pullen \\ Ohio Northern University \\ j-pullen@onu.edu
}

Review of

Hergenrader, Trent. Collaborative Worldbuilding for Writers and Gamers. New York: Bloomsbury, 2019.

Beginning to read Trent Hergenrader's book, Collaborative Worldbuilding for Writers and Gamers, I began by being interested and excited, having seen Hergenrader present on this project, long before the book came to fruition. My excitement was not misplaced. I am struck by how incredibly timely Hergenrader's book is, and how important it may turn out to be to creative writing as a discipline within the academy, not just now, but in the future. This book enters a storytelling landscape in which large expansive transmedia storytelling worlds, such as that of Marvel, Harry Potter, or Star Wars, are omnipresent in popular culture. As such, many of our students will come to the classroom, now, and for several generations of students to come, profoundly influenced by fictional worlds that are the product not of one creator, but of many. While I personally am an avid consumer of the above worlds, many people are not, and Hergenrader's book, intended as a guide for gamers, teachers, and writers, not just educators - has the most profound implications for helping educators either lead collaborative worldbuilding classes, or at the very least, understand more about the vast expansive, multi-author and multi-platform stories that have influenced many of their students.

The book begins with an overview of its purpose, an explanation of what collaborative worldbuilding is, and what it can be used for. The text is intended to be both theoretical, and practical. Hergenrader takes great care to describe the vast array of uses for the text, particularly pedagogically, saying it can be used in history classes, literature courses, or writing courses (3). Even ignoring the potential uses for role-playing games, like Dungeons and Dragons, the array of applications is staggering. The audience for this text is also impressively large, given that it spans disciplines within academia, as well as potential purposes, from teaching students how to be more effective writers of speculative fiction, to "encouraging students to think critically about forces at play in different kinds of fictional 
worlds" (3). Hergenrader even suggests it could be used to analyze real historical periods. One could use the techniques within to examine social forces in Beowulf, Oliver Twist, or Ohio in the Great Depression. While such a wide applicability could seem ambitious, Hergenrader has clearly taken great care to make the book a tool useful in many situations.

Hergenrader places his book, and worldbuilding as a classroom activity, in its context, discussing both its advantages and disadvantages. The care he takes to acknowledge the scholarly literature on worldbuilding, as well as to discuss that literature in accessible, jargon-free language, is admirable, and is a testament to the large intended audience. He describes the overview of the project, what the book will contain, from a description of what you will need to apply the concepts within the book, key terms, and what examples of transmedia collaborative story worlds he will use for illustrations (Star Wars, Lord of the Rings, Dungeons and Dragons, and A Song of Ice and Fire). With his description of the book, Hergenrader prepares the reader for the text to come.

The scaffolding offered in the introduction is emblematic of how devoted Hergenrader is to the accessibility of his text. The beginning chapters scrupulously supply information that readers unfamiliar with transmedia storytelling, or speculative fiction, would find deeply necessary. Yet, these chapters are also short, allowing a reader already intensely familiar with vast fictional universes, and the many genres available to them (such as cyberpunk, post-apocalyptic, steampunk, or high fantasy) to not spend too much time on things they already know. Conversely, for those unfamiliar, Hergenrader not only describes the characteristics of various speculative fiction genres, but also, how these genres lend themselves to different types of stories, and different themes. For example, he discusses both the dangers and potential advantages of fantasy fiction's ability to contain multiple races of sentient beings (such as elves, orcs, etc.). He says they can offer a "vocabulary for discussing potential biases or tensions that exist within each group" (25). He also warns against the dangers of essentialism in fictional worlds. Throughout the initial chapters, Hergenrader offers a guide for using the book, but also an argument for how such a project can do more than help students write expansive and detailed stories, but also foster critical thinking skills and an awareness of the ways in which the individual is influenced by the society in which they live.

Hergenrader's argument about the power of collaborative worldbuilding to enhance critical thinking and student social awareness continues throughout the text, but is especially present in chapters four ("Frameworks of Fiction Worlds") and five ("Structures and Substructures of Fictional Worlds"), in which he describes how to construct a world, from recognizing the interrelationship between governance, social relations, and cultural influences. He moves fluidly and effectively between describing how to keep a classroom on-task and productive during the initial process of deciding what type of world to build, the scope of the world (asking the reader to decide if their story will take place within a vast galaxy, like Star Wars, a particular continent, like Lord of the Rings, or just a castle, like Gormenghast), and the implications of those choices. For instance, after describing different types of 
worlds, and scope choices (from vast to small) Hergenrader talks, very practically, about how these choices affect things like point-of-view, and other concerns relevant to fiction writers. In chapter five, Hergenrader details what he refers to as "structures" pulling from other disciplines like sociology, in order to talk about how structures like "governance," "economics" and "social relations" impact the world, and hence, characters.

It is in his analysis of the role of structures in collaborative worldbuilding that Hergenrader's argument about how worldbuilding can make students more socially aware and better critical thinkers really comes to the fore. In a society with intrusive governance, how does that manifest? Are some populations within the world subject to disproportionate enforcement? If so, how does that manifest socioeconomically? How might those forces affect the lives and decisions of characters? The questions Hergenrader brings up are questions that I as an educator am likely to ask my students when analyzing a fictional text, to see how the text makes cultural critiques. They are the type of questions I (and probably most educators) want my students thinking about when reading and writing, the type of questions that make for more engaged and open citizens of the world. Hergenrader makes clear that if students take their worldbuilding project seriously, they will inevitably have to think about how real people in our world are subject to similar forces. In this way, one of the crucial contributions of the collaborative worldbuilding project becomes abundantly clear. Not only is the text timely insofar as transmedia storytelling is growing in popularity, it is timely in its potential to allow students to grapple with social issues central to the 21st century. Hergenrader also covers the history of role-playing games and their influence on collaborative worldbuilding (especially Dungeons and Dragons) and how role-playing games can guide the creation of catalogs of important people, places, objects, and events in your fictional world. The remainder of the book is mostly devoted to practical concerns, the how of collaborative worldbuilding. Yet even while leading the reader through the practical how-to aspects of collaborative worldbuilding, Hergenrader slowly yet persuasively shows the pedagogical value of collaborative worldbuilding.

Even while focusing on teaching the reader how to use the book, Hergenrader peppers the book with illustrations from his example transmedia storyworlds, and from a hypothetical collaborative world built using his system. The effect of his use of narrative examples keeps the instruction manual sections from being too dry and allows Hergenrader to continually demonstrate the ways in which collaborative worldbuilding can make students more conscious citizens, and better writers. The straightforward nature of the instructions, and the argument for relevance through examples, rather than standard expository argument, makes the text feel transparent and easy to use. Furthermore, the inclusion of a website with example syllabi, recommended programs, and other resources, makes this book a living guide. While I find myself feeling impressed (and a tiny bit intimidated) by the amount of time that Hergenrader, a professor at the Rochester Institute for Technology, clearly devotes to creating his collaborative worldbuilding course, I do feel that the book and the companion website are enough to 
equip any teacher who wants to lead a class that uses collaborative worldbuilding.

Furthermore, while the text is meant to be used by gamers, and writers, it feels most relevant to educators, given the consistent focus on the ways the book can be used to guide others in creating textbased stories. It also acts as a kind of argument for the worthiness and inclusion of genre fiction in the creative writing curriculum, something that many a professor, myself included, see as an issue important to address for the purposes of drawing students, and having inclusive aesthetics. It also functions as an argument for creative writing's purpose going beyond simply grooming students to be authors, that in fact, through conscious course design, creative writing can help make students better thinkers and global citizens. Hergenrader's belief in the value of creative writing in shaping the beliefs and behaviors of students is evident in the Coda: "Building Worlds Together:"

[...] this book has another equally important purpose in the space of our primary world, the one we inhabit. I hope this book can bring people together, and I hope it creates space for dialogue around difficult questions, especially for people who may see our world in very different ways. In order for a collaborative worldbuilding project to succeed, it requires respect, patience, and compromise from every contributor. Worlds are not monolithic, and they are not univocal. They are fluid and transitory, and we know it to be that whole cultures' attitudes, opinions, and beliefs shift over time. A world's history is not a single incontrovertible narrative, but rather an aggregation of a number of subjective viewpoints [...] It could be argued that we reach the deepest understanding of a given place in a given time if we listen to the stories of the people who live there. (224)

Given the overall divisiveness of the current cultural moment, and the simultaneous crisis within much of the humanities, increasing creative writing's relevance and appeal as a discipline is much on the mind of faculty and administrators. If we as creative writing teachers can increase the relevance of our discipline by tackling the type of storytelling students are interested in, while simultaneously helping those students grapple with thorny cultural issues, why wouldn't we? Hergenrader's book offers one way to deal with some of the challenges we face as a discipline, and does so in a clear, cogent, and unpretentious manner, that allows him to successfully appeal to the broad audience he aspires to. 